\title{
水稲画像のマッチング手法の開発
}

\section{A Matching Algorithm for Rice Plant Images}

\author{
串田圭司*, 吉野邦彦*, 山路永司* \\ Keiji KUSHIDA, Kunihiko YOSHINO, Eiji YAMAJI
}

\begin{abstract}
Abstract : 3-D measurement of rice canopy is effective for growth analysis, photosynthesis evaluation, and reflectance modeling. But, digital measurement has been hardly carried out because 3-D measurement of plant canopy is difficult.

In this paper, past studies on stereo matching are reviewed and it is shown that not only information of similarity but also that of continuity is necessary in order to match each point of rice vertical images. Therefore, a new matching algorithm for rice plant images is proposed. The algorithm is based on recognition of the top of a leaf and a following outline of the leaf. Rice 3-D shape was measured presicely with this algorithm.
\end{abstract}

\section{1.はじめに}

植物群落の立体的な構造の計測は, 生長解析, 光合 成能の評価など植物群落そのものを知るために必要で ある。さらに,リモートセンシングによる生育状態把 握の研究においても必要不可欠である1。従来, その計 測は農学, 植物形態測定の分野では, 層別刈り取り法, ポイント法, 投影法など測定に労力を要する測定法 ${ }^{2)}$ によっていた。これらの方式については, 労力を軽減 し, 迅速に撖密な立体的な構造の考察を行う計測手法 の開発が必要である。

これに対し測量, 工業, 医療の分野では，3 次元ディ ジタル計測法として, ステレオ写真測量による方法(ス テレオ写真法), アクティブステレオ法, レーダによる 方法，CT スキャンによる方法などが使われてきた しかしそれらの方法は, ステレオ写真法を除いては複 雑な設備を要するため, 野外で植物群落のように比較 的大きなものを測定するには不便である。

以上の背景のもとで本研究は, 今まで植物の立体構 造の複雑さのために困難(4)であるとされてきたステレ オ写真法におけるディジタルマッチングを, 水稲の鉛

* 東京大学農学部

「写真測量とリモートセンシング」Vol. 33, No. 3, 1994
直画像に適用するためのディジタルマッチングアルゴ リズムを提案し，水稲個体群の 3 次元ディジタル計測 を行うものである。

\section{2. 既往の画像マッチングによる 3 次元計 測法の水稲への適用性}

ディジタルマッチングは, ステレオ写真による地形 図作成, 動画像の解析などの目的で研究開発されてき た。これらは, 画像相関法によるマッチングと特徵マッ チングに分けられることが多いが，両者の併用が最近 の研究では注目されてきている。ところで，ほとんど の既往のマッチング手法は，そのアルゴリズムを次の 4 つの段階に分けることができる。

(1)画像の前処理 (pre-processing)

エッジの強調や Gaussian フィルタによるフィル夕 リングなどが行われる。人間の目の生理的な機能を応 用した Marr-Poggio マッチングでは何段階かのフィ ルタリング5)が行われる。これによると相似性による 対応点決定精度を向上させる効果がある。

(2)マッチングのために用いる点 (candidate) の選択 画像中の全ての点についてマッチングを行うこと は, 計算時間の問題のほか, マッチングが難しい点に よって生じる誤差が大きくなるなどの問題がある。そ のため, エッジ上の点や, ゼロクロッシングの点を選 
択することが行われる。なお，マッチングに用いられ なかった点は, (4)の画像の再構築の段階で処理される。

(3)相似性（similarity）と連続性 (continuity) の評

\section{価}

対応点を決定するために利用できる情報は，対応点 近傍の画像の相似性と対応点の集合の各画像内および 3 次元的な連続性の 2 つに分けることができる。

相似度の指標としては, 相関係数や絶対值のほか エッジの傾きなども用いられる。地形の写真測量にお いては，一般に面積相関法が用いられる6。

連続性の考慮は対応点決定の際用いられる場合と, 全対応点決定後, 補正として用いられる場合 ${ }^{7}$ がある。 前者の一例である弛緩法は，ある点と対応点であると いう確率をその近傍の点のそれとの比較によって更新 していくというものである。

相似性と連続性の両者を取り入れた評価関数を用い たダイナミックプログラミングによる評価8)開発さ れている。また，画像認識の分野では，直方体や円柱 の認識とそれらの形状によるマッチングも取られ $3^{9)}$ 。

(4)画像の再構築 (reconstruction)

この段階では, (2)の段階でマッチングのための候補 点として選択されなかった点抢よび対応が得られな かった点の奥行きを, 対応が得られた点の奥行きから， 何らかの内挿法により推定することが行われる。そし て全体画像として再構築する ${ }^{10)}$ 。

以上のようなマッチング手法を，水稲画像に適用す るに当たっては, 次のような問題点がある。

問題 1 ）対応点に扔ける相似性が小さい

水稲の鉛直画像のように，奥行き方向の変位がフィ ルム面方向に比べて大きいステレオ画像では, 左右の 投影歪みが大きい。例之ば，基線比を $\mathrm{r}$, 個葉の傾きを $\alpha$, 個葉の方位角を $\phi$ (基線と平行な時 $\phi=0$ ) とする。 個葉は, 左右カメラから等距離の所に位置し, 標定計 算は正確に行われたと仮定すると, 左右画像でのこの 個葉の輪郭線の傾きのずれ $\theta$ は,

$$
\theta=\tan ^{-1}\left(\frac{r \tan \alpha \sin \phi}{2-r \tan \alpha \cos \phi}\right)+\tan ^{-1}\left(\frac{r \tan \alpha \sin \phi}{2+r \tan \alpha \cos \phi}\right)
$$

となる。ここに, $\alpha=75$ (度), $\mathrm{r}=1 / 6, \phi=90$ (度) とすると， $\theta=35$ (度) と大きくずれることになる。

このため, 水稲個葉の輪郭に相当する点では, 対応 点であっても，エッジの傾きが一致しない。
また，水稲個葉内部のテクスチャは相似性が大きい ため, 回転に対する保存量を用いてもマッチングが難 しい。

このように相似性による評価を，水稲内各点につい て行うのは難しい。

問題 2 ) 不連続性が大きい部分が多く存在する。

水稲部分と土壤部分, 及び異なった個葉が, 3 次元 的に不連続であるため，その部分で画像の再構築がで きない。しかも奥行きの差が大きいため, 同一相関空 内に両者が含まれているときには，それぞれ別の相関 空に含まれる部分と対応することが多い。これは，問 題 1 ）にも影響を及ぼす。

\section{3. 葉エッジマッチング法のアルゴリズム}

本論文で提案する水稲画像のマッチングの新しい方 法である葉エッジマッチング法, すなわち個葉の先端 の対応とそれに続く個葉の輪郭のエッジとしての認識 によって, 対応点を求める手法について, 以下に説明 する。

\section{3-1 マッチングの考え方}

先に検討した問題 1) を解決するためには, 相似性 より連続性に重きを置く必要がある。しかし, 連続性 だけでは対応点は決定できず，いくつかの点での相似 性によるマッチングが必要である。相似性によって対 応できる点としては, 個葉の先端を選ぶ。個葉の先端 の認識は先述の投影による歪みの影響を受けない量に よって行うことができる。また，十分解像度を高めれ ば, 異なる個葉の先端は異なるラインに存在すること から区別できる。

そして, 連続性の判断が比較的容易な個葉の輪郭線 をマッチングの対象とする。この方法ではすべての候 補点については, 相似性による評価を行わないため, 弛緩法やダイナミックプログラミングによる方法の意 義は薄い。個葉内部の各点の高さはそれに最も近い個 葉の輪郭の高さにほぼ等しいと言えるから, 直接マッ チングせず，内抻により再構築する。

個葉の輪郭線を連続性によりマッチングするために は, 個葉の重なり部における輪郭線の接続の判定と, 輪郭線の追跡においてノイズの影響を受けないことが 求められる。そこで, 輪郭線をエッジとして抽出し, さらにそれを細線化することによって得た線セグメン 
トの分岐点, 交差点における接続の判定を行う。エッ ジ検出オペレータのみによる輪郭線抽出によると, 輪 郭線の途切れが生じるため, 最尤法により水稲部分を 他の部分から分離することを用いる。

また, 問題 2）を解決するために水稲部分と土壌部 分を切り離して扱う。本研究においては, 土壤部分の 情報は必要ないから水稲部分のみ取り出してマッチン グすればよい。個葉と個葉の重なりによって生じる不 連続部分についても, それを認識し, 連続する単位ご とに分離すればよい。これは問題 1）の接続の判定へ の対策と両立する。

\section{3-2 マッチングのアルゴリズム}

本マッチング手法のアルゴリズムは, 次の仮定に基 づいている。

仮定 1 ) 偏位修正画像において, 各個葉の先端はそれ ぞれ異なるライン (エピポーラ線 $\left.{ }^{11)}\right)$ 上にあ る。

仮定 2 ) 個葉の輪郭線は濃度変化の大きい部分として のエッジと一致する。

仮定 3 ) 個葉の輪郭線は十分滑らかである。

これらは, 写真撮影の照明条件, スキャナ一の解像 度に留意すると，一般にほぼ成り立つと考之られる。

マッチングのアルゴリズムのうち, 分岐点の処理を 図 1 に, 個葉の先端の認識とそれに続く輪郭線の追跡 を図 2 に模式的に示す。また，図 3 にマッチングのフ ローの概略を示すが, 詳細は次の通りである。

(1) 対応点の 1 次元探査のため, 左右画像の対応点が 同一ライン上に存在するよう，偏位修正を行う。原画 像から偏位修正画像へリサンプリングする時には，バ イリニア法を用いた。

（2）最尤法により，水稲部分を他の部分から分離する (写真 1 )。水稲, 明るい土壤, 暗い土壤など数個の力 テゴリーを設定し, 正しく分類できるまで試行錯誤を 行う。ここでは, Erdas社のソフトウエアを用いた。

（3）微小面積のかたまりをノイズとして除去する。

(4) 左右画像水稲部分における平均, 分散が一致する よう，線形式による濃度補正を行う。

（5）水稲部分のエッジを抽出する。ここでは, Prewitt のオペレータ ${ }^{12)}$ を用いた。ノイズが小さくなるようし きい值を設定する。


Hilditchの方法 ${ }^{13)}$ を用いた。
（7）線画像のセグメント化により，分岐点，交差点を 抽出し, これらが連結点となるように隣接する連結点 において分離を行う（図 1 )。この際，個葉の輪郭線を 接続した状態で保つため, 仮定 3 ）により，最も滑ら かなもの以外を分離する。その判断は次のアルゴリズ ムに従う。ただし, 線セグメント上の画素を 1 画素と 呼ぶ。以下分岐点であるとして説明を行う(図 4 参照)。 交差点であっても同様である。

i ) 分岐点 $\mathrm{P}$ は 3 つの隣接する画素 $(\mathrm{a}, \mathrm{b}, \mathrm{c})$ を持っ ている。これらにおいて分岐点から 5 連結以上の線 セグメントに A などのラベルをつける。また分岐点 から 5 番目の画素を便宜的に端点と呼び $\mathrm{a}_{1}$ などと する。同一のラベルの線セグメントが画素を共有す ることはあるが(図 4 のC), 異なるラベルでは画素 を共有しないようにする。

ii ） $\mathrm{f}(\mathrm{S}, \mathrm{T})$ は分岐点 $\mathrm{P}$ とその周りの任意の線七グ メント $\mathrm{S}, \mathrm{T}$ の端点 $\mathrm{s}_{1}, \mathrm{t}_{1}$ によって作られる角の大き

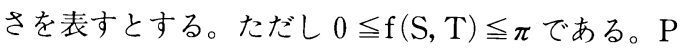
の周りのすべての線セグメントについて見たとき， $\mathrm{f}(\mathrm{S}, \mathrm{T})$ の最大值をとる線セグメントを連続と判断 し，他の線セグメントを $\mathrm{P}$ から分離する。図 4 では $\mathrm{A}-\mathrm{C}$ の組が連続と判断され, 線セグメント $\mathrm{B}$ を $\mathrm{P}$ から分離する。

(8) 左画像において, ライン番号の小さい方から大き い方へと個葉の先端を探索する。先端の認識は, 「連結 点であり, 上下どちらかのライン上の点とは連結しな いが，他の側では少なくとも 2 ライン異なる点まで連 結する点」によって行う。先端として認識する点の例 を困 5 に示す。

（9）右画像同一ライン (エピポーラ線）上で個葉の先 端の探索を行ない，対応づけを行う(困 2 )。高さの範 囲から限定できる部分について行う。先端に相当する 点が見つかると仮定 1）に基づき, これを対応点と決 定する。同一ライン上に個葉の先端が存在しないとき には，誤差を考慮して上下数画素まで探索する。

(10) 左右画像の対応した点と連結する $2 つ の$ 線セグメ ント各点の対応付けを行う。すでに決定された対応点 と連結する線セグメント上にあり，しかも左右画像に おいて，同一ラインにある点を次々に対応点として決 めていく。対応点が決まった線セグメント上の点は, 探索から除く。左右どちらかの追跡中の線セグメント が途切れたり，ラインが小さくなる方へが延びて行く 時や高さが高くなる傾向を持つ（個葉の先より茎に近 


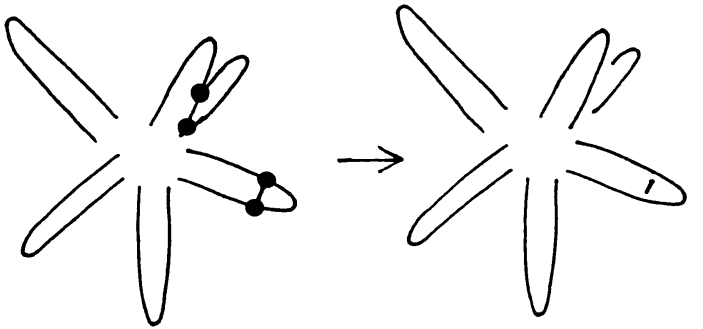

図 1 分岐点の処理

左画像 右画像

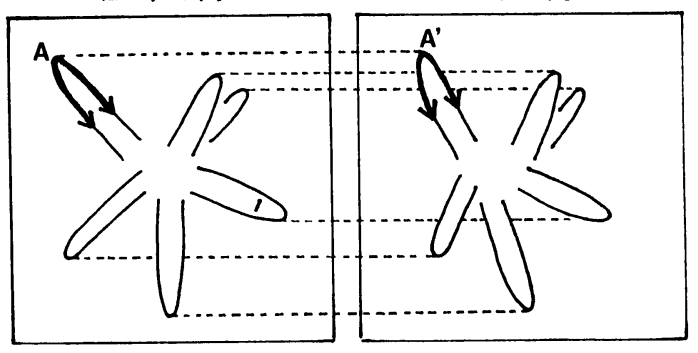

図 2 葉の先端の認識とそれに続く輪郭線追跡による対 応点の決定

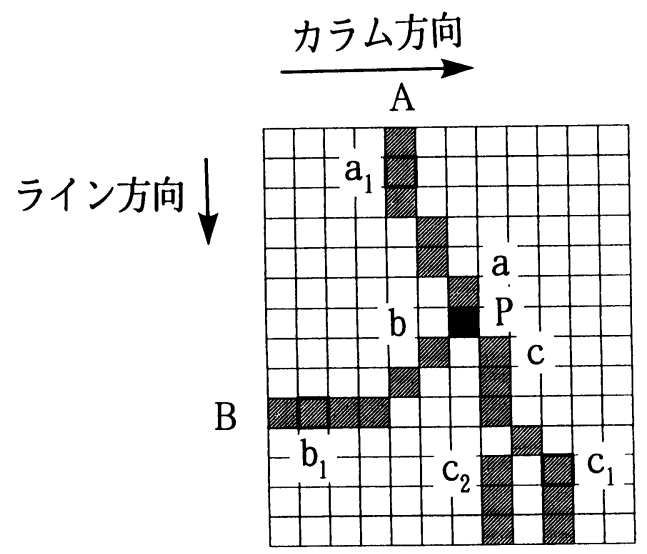

処理前

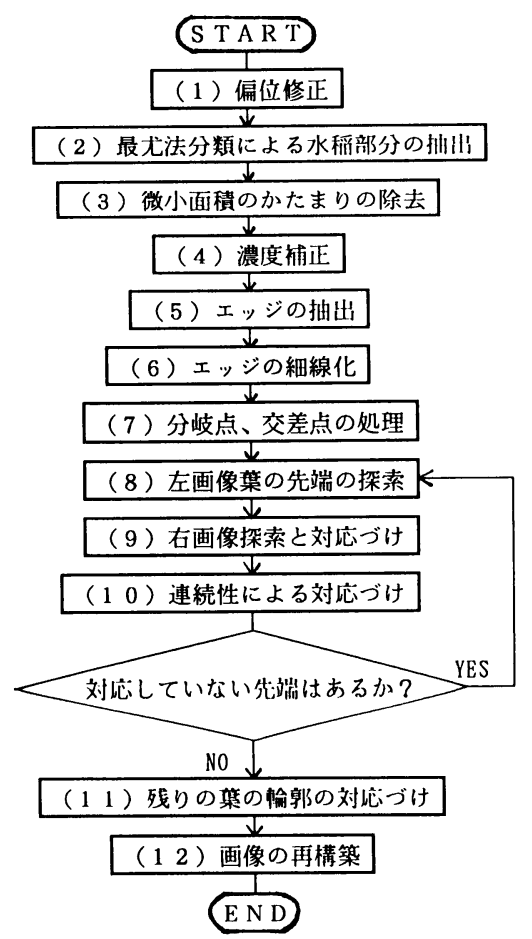

図 3 葉エッジマッチング法のアルゴリズム

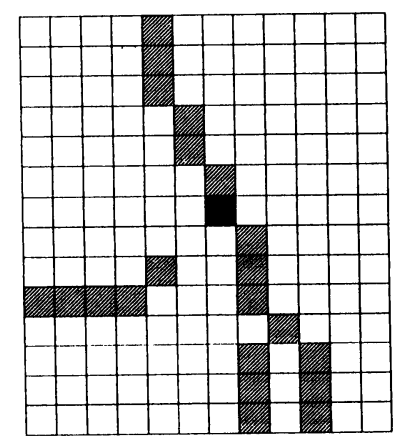

処理後

\section{$\square$ 分岐点P \\ 1 画素 \\ $\square 0$ 画素}

図4 分岐点の処理例

カラム方向

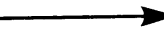

ライン方向

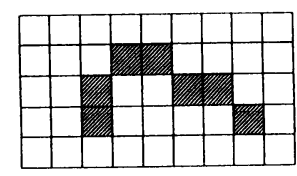

(a)
1 画素

$\square 0$ 画素

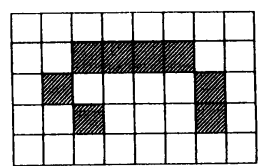

(b)

図 5 認識される先端の例 

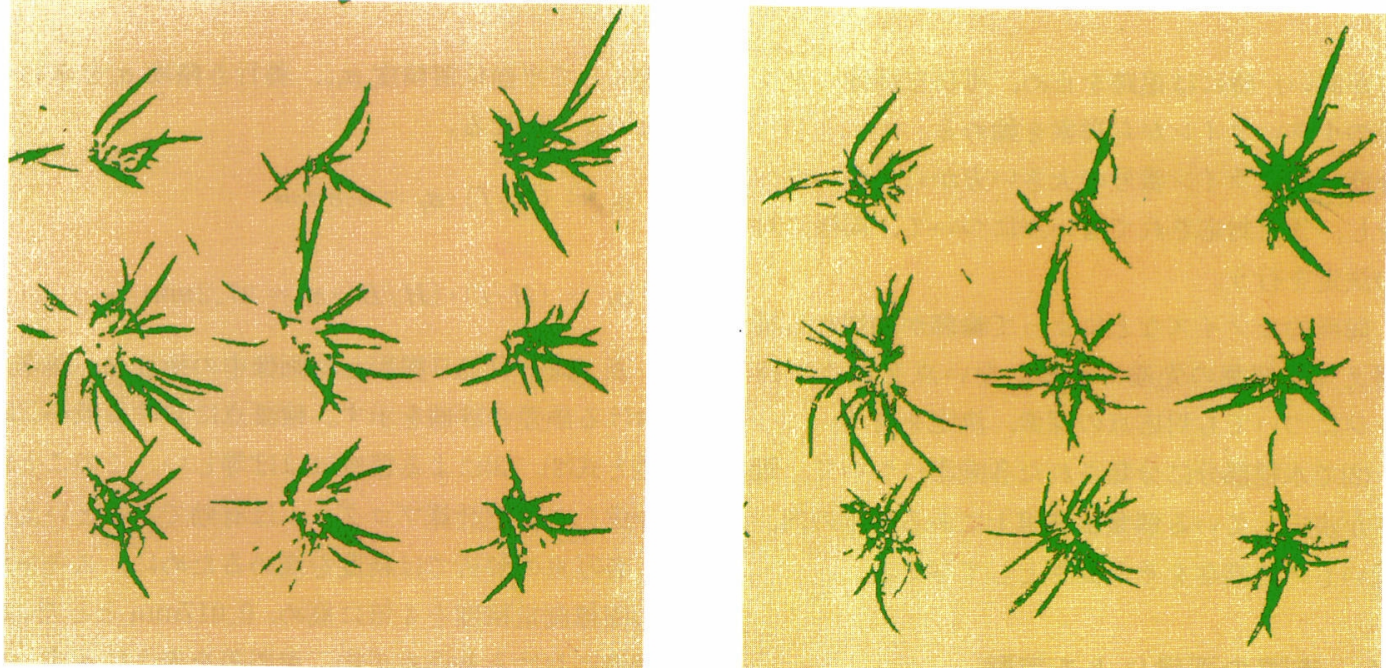

写真 1 水稲部分の抽出

左画像

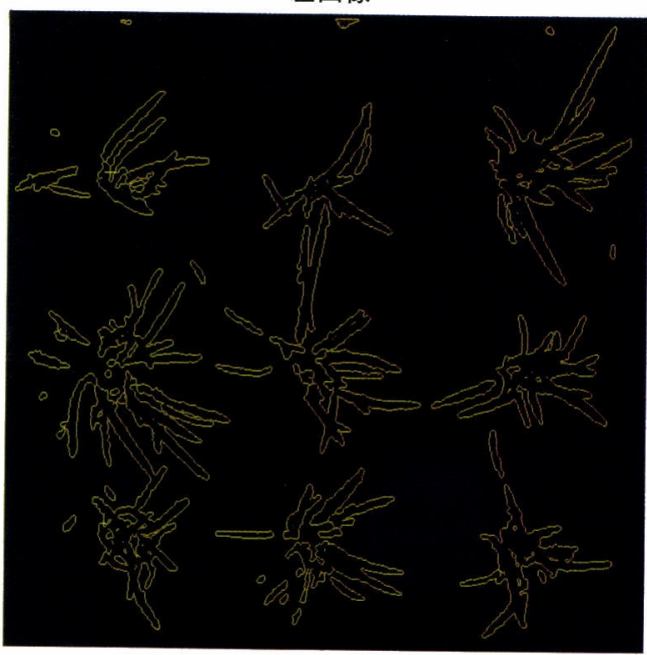

右画像

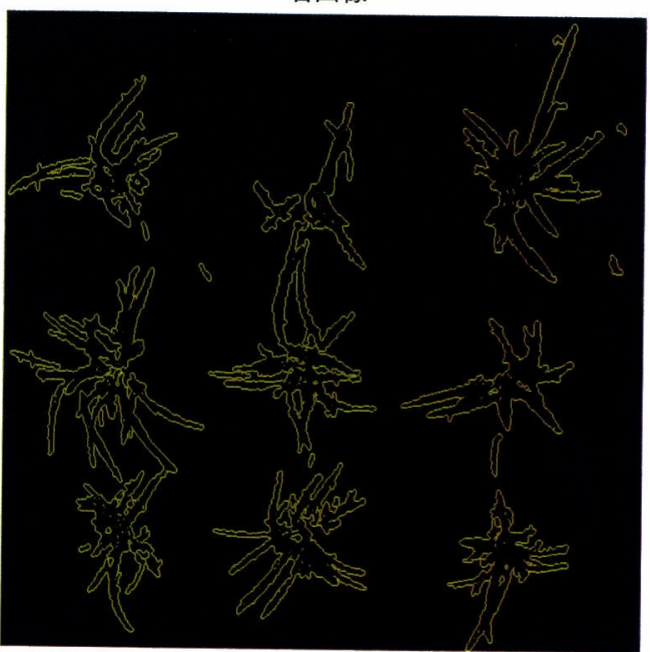

写真 2 葉の輪郭線の細線化

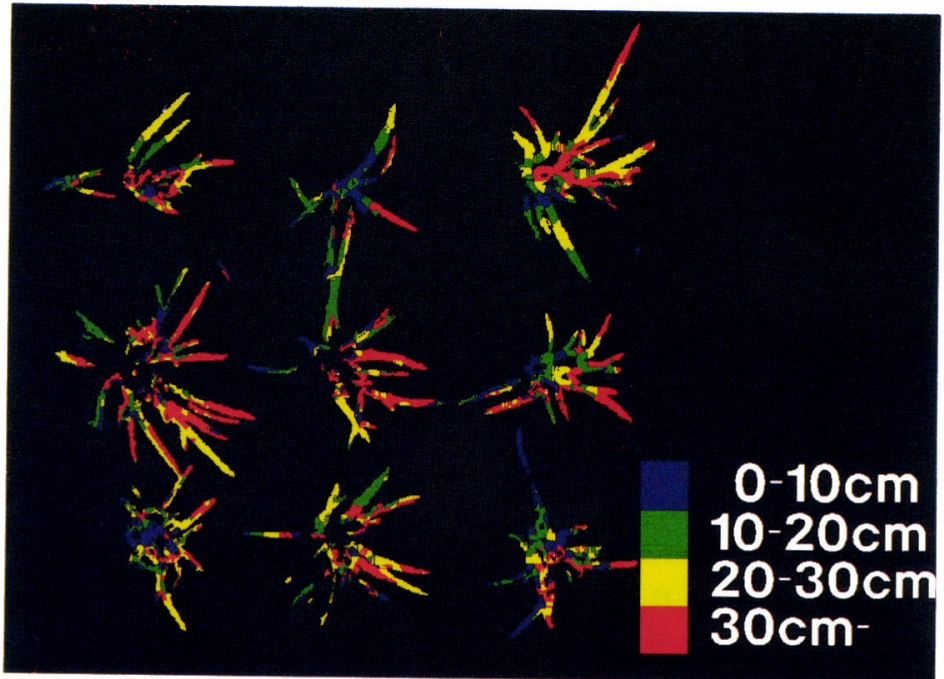

写真 3 水稲各部分の高さ 
い方が高い）時には追跡を止め, 再び左画像のライン 番号の小さいラインから探索を始める。

今度は逆にライン番号の大きい方から小さい方へ探 索をし, まだ対応されてない点について, 同様に対応 点の決定を行う。

(11) 局所的なノイズなどによって輪郭が途切れる場合 を考えて，個葉の先端に相当しない点を起点に持つ エッジについても対応点の探索, 決定を行う。

(12) (2)で水稲部分に分類された各画素について, 既に 高さが決定している個葉輪郭線上にある画素の内, 最 も近いものの高さをその高さとして与える。

\section{4.実際の画像による実験}

\section{4-1 写真撮影}

東京大学農学部構内のライシメータで水稲（コシヒ カリ）を栽培した。株と株の間隔は, $30 \mathrm{~cm} \times 30 \mathrm{~cm}$ と した。生育期間中に, $35 \mathrm{~mm}$ 一般カメラ (非計測用カ メラ，レンズ焦点距離 $28 \mathrm{~mm}$ ) によって鉛直方向からの 写真撮影を行なった(図 6 )。被写体までの距離 $\mathrm{H}=$ 約 $2.8 \mathrm{~m}$, 基線長 $\mathrm{B}=$ 約 $0.7 \mathrm{~m}$ ，基線比約 $1 / 4$ とした。基準 点は, 上段 8 点, 下段 8 点, 計 16 点を, 撮影対象の周 りを囲むようにして設けた。水稲の生長に伴い基準点 の位置を変えた。基準点の地上座標を，これらを写し 込む 1 組の写真を取る度に, セオドライト，レーザレ ベルによる測量によって求めた。

写真撮影によって得た左右写真はディジタル的に処 理するため，スキャナーでディジタル画像化した。 1 画素が写真フィルム上の $0.017 \mathrm{~mm}$ に相当するように した。基準点の画像座標は人間がモニター上でより読 みとる。

\section{4-2 標定計算}

標定計算は自作のプログラムを用いた。このプログ ラムにおいては 6 つの外部標定要素の他に主点の位置 ずれ，放射方向歪曲収差によるレンズディストーショ ン, フィルムの平面度の歪みといった $11 の$ 内部標定要 素も考慮した ${ }^{14)}$ 。

作成した標定要素計算プログラムの検証には，基準 点の他 4 点の検証点を設けた 6 月 25 日撮影の画像を用 いた。ただしこの検証では，1画素が写真フィルム上 の0.068mm に相当するようにした。カメラの焦点距離 $\mathrm{f}=28 \mathrm{~mm}$ と座標測定精度 $\sigma_{\mathrm{p}}=0.068 \mathrm{~mm}$ を式(2)，(3)に
代入して平面位置精度 $\sigma_{\mathrm{xy}}$, 奥行き精度 $\sigma_{\mathrm{z}}$ を求めると 次のようになる。

$$
\begin{aligned}
& \sigma_{\mathrm{xy}}=(H / f) \cdot \sigma_{\mathrm{p}}=6.8 \mathrm{~mm} \\
& \sigma_{\mathrm{z}}=(H / f) \cdot(H / B) \cdot \sigma_{\mathrm{p}}=27.2 \mathrm{~mm}
\end{aligned}
$$

表 1 に 6 月 25 日撮影した画像中の検証点, 基準点に おける誤差の評価を示す。検証点における最小二乗䛊 差と式(2)，(3)による精度はほぼ等しい。このことから 作成した標定計算プログラムは有効であるといえる。

各写真の解析では精度を高めるために，スキャナー の座標測定精度を 4 倍に高め, $0.017 \mathrm{~mm}$ とした。標定 計算における基準点平均二乗誤差を表 2 に示寸。地上 座標誤差は, X, Y, Z 成分を順に示す。画像上誤差が座 標測定精度を高める前の結果に反し，1画素より大き くなっているのは，画像が十分鮮明でなかったことに よると考えられる。

\section{4-3 マッチング状況の評価}

6 月 25 日と 7 月 16 日の写真画像を用いて本手法の実 験を行った。6 月25日の処理の様子は写真 1 , 写真 2 に既に示した。

各画像中の 1 株についてのマッチング状況を表 $3 に$ 示す。原画像において実際の対応点を求めるのは極め て困難である。そこで, 輪郭線に注目した目視によっ て得た, 細線化画像における対応と本手法によって得 た対応とを比較した。これらが異なる場合は, 誤って 対応した点として数えた。細線化画像における対応は 厳密には, 原画像における対応と異なるため, 表 3 で 正しくマッチングされた点としているものも微妙に誤 差を含む。この誤差はディジタル化, 標定計算, 輪郭 線抽出に伴うものである。ただし，ここで誤って対応 した点としたものの誤差に比べて，はるかに小さい。

表 3 によると, マッチングの候補点の内約 7 割が マッチングされた。6 月25日の画像ではその内の約 9 割, 7 月16日の画像では約 8 割が, 細線化画像との比 較において，正しくマッチングされている。候補点の 内，マッチングされなかった点が存在するのは，隠蔽 部分の影響や輪郭線抽出に伴う誤差によるものと考之 られる。対応点を誤った主な原因は，輪郭線の追跡の 途切れであった。6 月25日より7月16日の方が誤って マッチングされた点数が多いのは，個葉と個葉が重な る部分の割合が大きくなるためであると考えられる。 


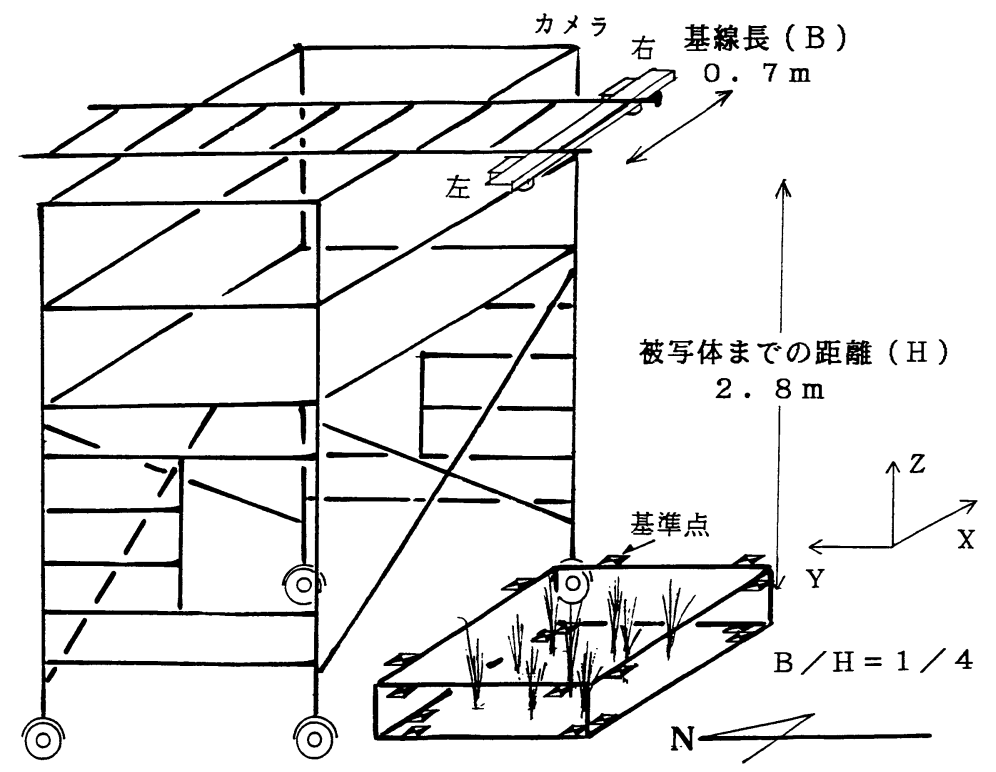

図 6 撮影方法

表 1 標定計算の誤差の評価

\begin{tabular}{|c|c|c|c|}
\hline & X成分 & $\mathrm{Y}$ 成分 & $Z$ 成分 \\
\hline 基準点平均二乗誤差 & 3.7 & 3.2 & 10.8 \\
\hline 検証点平均二乗誤差 & 5.8 & 7.7 & 24.8 \\
\hline デ仢多化より予想される誤差 & 6.8 & 6.8 & 27.2 \\
\hline
\end{tabular}

表 2 標定計算における基準点の平均二乗誤差

\begin{tabular}{|c|c|c|c|}
\hline \multicolumn{2}{|c|}{} & 6 月 25 日 & 7 月 16 日 \\
\hline \multirow{2}{*}{$\begin{array}{c}\text { 外部標定要素のみ } \\
\text { (画素数) }\end{array}$} & 左画像 & 2.88 & 2.76 \\
\cline { 2 - 4 } & 右画像 & 3.25 & 2.93 \\
\hline $\begin{array}{c}\text { 外部および内部標定要素 } \\
\text { (画素数) }\end{array}$ & 左画像 & 2.39 & 2.31 \\
\cline { 2 - 4 } & 右画像 & 2.17 & 2.24 \\
\hline \multicolumn{2}{|c|}{ 地上座標 $(\mathrm{mm})$} & $(5.8,4.7,14.4)$ & $(5.4,6.4,15.0)$ \\
\hline
\end{tabular}

表 3 マッチングの誤差

\begin{tabular}{|c|c|c|}
\hline & 6 月 25 日 & 7月 16 日 \\
\hline 画像のサイズ（カjム×ライリ） & $200 \times 370$ & $400 \times 340$ \\
\hline マッチングに用いた点数 & 1543 & 4075 \\
\hline マッチングされた点数 & 1063 & 3193 \\
\hline 誤ってマッチングされた点数 & 145 & 668 \\
\hline
\end{tabular}

表 4 各株の最高位点における高さ算出の誤差（ 6 月2 25 日)

\begin{tabular}{|c|c|c|c|}
\hline & 実測値 & 計算値 & 犃差 \\
\hline a & 420 & 443 & -23 \\
\hline b & 370 & 400 & -30 \\
\hline c & 420 & 454 & -34 \\
\hline d & 495 & 487 & 8 \\
\hline e & 475 & 438 & 37 \\
\hline f & 425 & 458 & -33 \\
\hline g & 382 & 372 & 10 \\
\hline h & 430 & 420 & 10 \\
\hline i & 415 & 466 & -51 \\
\hline
\end{tabular}

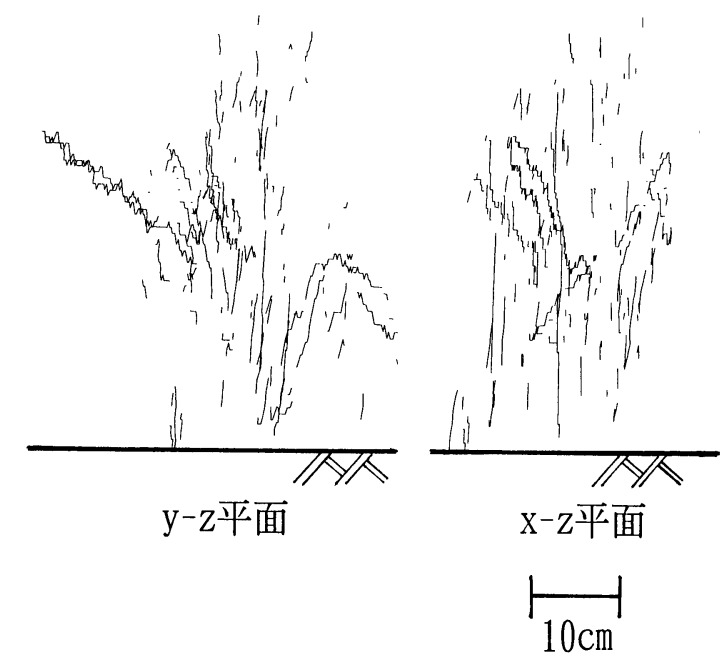

目 7 計算による葉輪郭線の投影図

また，各株の高さの実測值と計算值との差を表 4 に 示す。各株で最も高い位置にある個葉の先端の高さを ものさしで測り，実測值とした。また，高さを測った 個葉の先端に相当する左画像上画素において, 本手法 で得た高さを計算値とした。これによると 3 次元座標 算出が正確に行われているといえる。

偏位修正済み左画像上で，本手法によって得た 6 月 25 日水稲各部分の高さを表したものを写真 3 に示す。

さらに, 対応点の得られた各画素に相当する 3 次元 
座標を $\mathrm{Y}-\mathrm{Z}$ 平面, $\mathrm{X}-\mathrm{Z}$ 平面に投影したものを図 7 に 示す。

\section{5. 結論と課題}

\section{5-1 結 論}

水稲などの植物のステレオ画像のマッチングは難し いといわれていたが，まずそれを行う際の問題点を整 理した。既往のステレオ画像マッチングは, 画像の前 処理, 用いる点の選択, 相似性の評価, 連続性の評価, 画像の再構築からなる。これらのうち相似性の評価を 水稲鉛直画像全体について行うのは困難であり，また 不連続部分が多く存在するために，その認識が必要で あることを示した。

このことを考慮して，新しく葉エッジマッチング法 を提案した。このアルゴリズムは個葉の先端の対応と, それに続く個葉の輪郭のエッジとしての認識によっ て, エピポーラ線を利用して対応点を求めるというも のである。さらに，この手法を実際の画像に適用して マッチング状況を評価した。この結果，水稲のような 複雑な形状を持つ対象のマッチングが可能になったと 言える。この手法は, 水稲ばかりでなく複雑な構造を 持つ植物の生長解析, 光合成能の評価のほか, リモ一 トセンシングによる生育状態把握の研究に利用できる と考えられる。

\section{5-2 今後の課題}

今後の課題として次の 3 点を挙げる。

1) 隱蔽部分の処理

実際には隠蔽部分の問題があり, 仮定 $2 ）$ が厳密に は, 成り立たない。この解決のためには, 線図形の特 徵に着目し, 隠蔽部分を推定するアルゴリズムの開発 が求められる。

2 ) 他の個葉の陰となる個葉の取扱い

本アルゴリズムでは他の個葉の陰となる個葉は取り 扱っていない。

近赤外域の波長带では個葉を透過する割合が高いた め, 赤外写真によれば, 他の個葉の㓌になる個葉の輪 郭線もエッジとして抽出, マッチングすることもでき
ると考えられる。

3 ）個葉の先端のマッチング精度の向上

本手法の精度は個葉の先端のマッチング精度による ところが大きいが, これを向上させるためには一画素 に相当する実際の大きさを十分小さくすること，また， それに応じた標定計算の精度を高めることが重要であ る。

なお，写真のディジタイズの際には堂満一成氏 (NHK) 作成のユーティリティプログラムを使わせて 頂いた。ここに感謝致します。

(受付1994.1.11, 受理1994.5.20)

\section{参考 文 献}

1) Asrar et al.: Theory and applications of optical remote sensing. (Wiley) pp. 142-143, 1989.

2) R.B. Mineni et al.: A Review of the Theory of Photon Transport in Leaf Canopies. Agr. and fore. Meteorol. 45, 8-23, 1989.

3 ) 井口征士ほか : 「次元画像計測」(昭晃堂), p.13-14, 1990.

4) 大政謙次ほか：「植物の計測と診断」(朝倉書店), p. $165,1990$.

5 ) W.E.L. Grimson : Computational experiments with a feature based stereo algorithm. IEEE Trans. PAMI -7(1), 17-34, 1985.

6 ）森忠次, 服部進, 内田修: 分割画像ごとの相関法によ る空中写真からの自動図化. 写真測量とリモートセンシ ング24(1), 13-22, 1985.

7) R. Mohan, G. Medioni, R. Nevatia: Stereo error detection, correction, and evaluation. IEEE Trans. PAMI-14(2), 113-120, 1989.

8 ) S.T. Barnard, W.B. Thompson: Disparity analisys of images. IEEE Trans. PAMI-2(4), 333-340, 1980.

9 ) H. Maitre, W. Luo : Using models to improve stereo reconstruction. IEEE Trans. GE-14(2), 269-277, 1992.

10) S.J. Dickinson, A.P. Pentland, A. Rosenfield: 3-D shape recovery using distributed aspect matching. IEEE Trans. GE-14(2), 174-198, 1992.

11）服部進，森忠次：計算機によるステレオマッチング手 法と自動相関機の現況. 写真測量とリモートセンシング 25(1), pp.21, 1986.

12）田村秀行ほか：「コンピュー夕画像処理入門」(総研出 版), pp.122, 1985.

13）前掲12）pp.83，1985.

14）(社)日本写真測量学会：「解析写真測量」改訂版, 1986. 